\title{
KANT'S NEGLECTED OBJECTION TO THE ONTOLOGICAL ARGUMENT
}

\author{
MICHAEL R. SLATER
}

Georgetown University

\begin{abstract}
This paper argues that Kant's most famous objection to the ontological argument - that existence is not a real predicate - is not, in fact, his most effective objection, and that his 'neglected objection' to the argument deserves to be better known. It shows that Kant clearly anticipates William Rowe's later objection that the argument begs the question, and discusses why Kant himself seems to have overlooked the force of this criticism in his attempt to demolish the traditional proofs for God's existence.
\end{abstract}

Many philosophers have thought that Kant's most significant and original criticism of the ontological argument is his objection that existence is not a real predicate (A599/B627), and there is little doubt that this is the most famous and influential of his criticisms of the traditional arguments for God's existence. ${ }^{1}$ Yet as William Rowe argued almost forty years ago, this objection does not clearly provide a conclusive refutation of the ontological argument, as it seems to rest upon some mistaken or incomplete claims about the nature of predication. ${ }^{2}$ Indeed, Rowe showed

${ }^{1}$ All references to the Critique of Pure Reason (1781/1787) are to the Cambridge Edition, translated and edited by Paul Guyer and Allen Wood (Cambridge: Cambridge University Press, 2008), and follow the pagination of the standard German Akademie edition of Kant's works.

${ }^{2}$ William Rowe, 'The Ontological Argument', in Joel Feinberg (ed.), Reason and Responsibility: Readings in Some Basic Problems of Philosophy, third edition (Encino and Belmont, CA: Dickenson Publishing Company, 1975), pp. 8-17. Reprinted in Steven M. Cahn (ed.), Ten Essential Texts in the Philosophy of Religion: Classics and Contemporary Issues (New York and Oxford: Oxford University Press, 2005), pp. 102-16. All page references are to the Cahn volume. 
that one can grant the proponent of the argument the assumption that existence is a real predicate, as well as the definition of 'God' as an existing, wholly perfect being, and still show him that it will not follow from that definition that there actually exists something to which his concept of God applies. ${ }^{3}$ Focusing his critique on Anselm's version of the argument, Rowe objected to the ontological argument on two basic grounds: first, that it does not follow from Anselm's concept of God that some existing thing must exemplify that concept, any more than it follows from the concept of a 'magican' (an existing magician) that some existing thing must exemplify that concept; and second, that the argument begs the question regarding the existence of God. ${ }^{4}$ Rowe's objections to Anselm's and other non-modal versions of the argument are successful, I think, but the latter of the two is hardly an original objection. ${ }^{5}$ What I want to show in this paper is that Kant in fact anticipates this objection in The Critique of Pure Reason, though he does not focus specifically, as Rowe does, on Anselm's version of the argument. ${ }^{6}$ If I am right, this neglected objection of Kant's deserves recognition on the part of philosophers of religion, not only insofar as it highlights another important and easily overlooked feature of his critique of the ontological argument, but also insofar as it highlights the cumulative nature of his critique.

A number of contemporary philosophers now think that Kant's critique of the traditional arguments for the existence of God in the First Critique was not only incomplete but also confused in some of its basic assumptions. In addition to the point about predication raised above, Kant's critique also seems to be incomplete insofar as it supposes that there are - and can only be - three types of theistic arguments (A591/ B619), which overlooks the possibility of other types of arguments for the existence of God such as the moral argument. And it is confused, some critics argue, insofar as it supposes that the teleological argument (or as Kant terms it, 'the physico-theological proof') is logically dependent

${ }^{3}$ Ibid., p. 112.

${ }^{4}$ Ibid., pp. 111-16.

${ }^{5}$ A modal version of the ontological argument such as Alvin Plantinga's does not fall prey to these criticisms, in my view, though I will not argue for this claim here. For Plantinga's defence of this version of the argument, see 'The Ontological Argument' in James F. Sennett (ed.), The Analytic Theist: An Alvin Plantinga Reader (Grand Rapids and Cambridge: Eerdmans Publishing Co., 1998), pp. 50-71.

${ }^{6}$ Kant seems to have had Descartes' version of the ontological argument in the Fifth Meditation primarily in mind, though he clearly thought that his objections to the argument applied equally to other versions as well. 
on the cosmological argument, and that the latter in turn depends for its success on the ontological argument and its attempt to demonstrate a priori the existence of a necessary being (A630/B658), with the consequence that a destruction of the ontological argument necessarily entails the destruct of the other types of arguments. ${ }^{7}$ Although I accept these criticisms, I will not undertake to defend them here, both for reasons of space and because my aim is to focus on what Kant gets right about the failings of traditional ontological arguments, as opposed to what he gets wrong. ${ }^{8}$

Before discussing what I have termed Kant's neglected objection to the ontological argument, though, it is perhaps worth noting that while a sympathetic critic such as Rowe disagrees with his claim that existence is not (or cannot be) a real predicate, along with the objection that Kant develops from this claim, he nevertheless shares with Kant - and is very likely indebted to him for - the basic assumption that 'from the

${ }^{7}$ Perhaps the most forceful and influential of these critics is Alvin Plantinga, who views this supposition as one of Kant's 'fashionable confusions about the ontological argument'. See 'Reason and Belief in God' in Alvin Plantinga and Nicholas Wolterstorff (eds.), Faith and Rationality (Notre Dame, IN: University of Notre Dame Press), pp. 16-93; for a more extensive critique of Kant's objections to the ontological argument, see Plantinga's 'The Ontological Argument', ibid. But even generally sympathetic interpreters such as Allen Wood have expressed serious doubts about the adequacy of Kant's views on the traditional theistic arguments, including the problematic assumption mentioned above. See Allen W. Wood, 'Rational Theology, Moral Faith, and Religion' in Paul Guyer (ed.), The Cambridge Companion to Kant (New York: Cambridge University Press, 1992), pp. 394-416.

For a fundamentally different interpretation of Kant's views on the traditional theistic arguments see Paul Guyer, who claims - in apparent contrast to what Kant himself states at A630/B658 - that 'for Kant the ontological argument is a more involuted line of thought' than the cosmological argument, one that leads 'from the existence of anything contingent to something necessary (the cosmological argument as the first step of the ontological argument), to the idea of a being comprehending all reality, and then as it were back down to the idea of the existence of this being as a necessary existence - following from its own concept and not being dependent upon and therefore possibly precluded by the existence of anything else'. See Guyer, Kant (London and New York: Routledge, 2006), p. 147. Guyer does not provide evidence for this surprising interpretation, however, and even if he is right this does not seem to affect the larger objection made by some critics that Kant's views on this matter are insufficiently developed.

${ }^{8}$ In putting the point this way, I simply mean to suggest that some of Kant's criticisms of medieval and modern versions of the ontological argument are successful. What I do not think Kant shows, however, is that his criticisms represent a successful refutation of any version of the ontological argument. Indeed, his assumption that this is essentially a single argument, rather than a family of closely related arguments, is itself problematic. 
logical analysis of a certain idea or concept we can never determine that there exists in reality anything answering to that idea or concept.' This assumption is clearly on display in the First Critique, where we find Kant arguing that given the principle that all existential propositions are synthetic as opposed to analytic (A598/B626), it follows that 'if I think of a being as the highest reality (without defect), the question still remains whether it exists or not. For although nothing at all is missing in my concept of the possible real content of a thing in general, something is still missing in the relation of my entire state of thinking, namely that the cognition of this object should also be possible a posteriori' (A600/ B628). ${ }^{10}$ As Kant summarizes this objection to the ontological argument, 'thus whatever and however much our concept of an object may contain, we have to go out beyond it in order to provide it with existence' (A601/ B629). ${ }^{11}$ This conclusion looks virtually identical to Rowe's first objection to the ontological argument, with the major difference being that Rowe arrives at this conclusion by granting the proponent of the ontological argument the assumption that existence is (or can be) a real predicate, which Kant of course does not. This constitutes an advantage of Rowe's version of the objection, I think, but the basic objection itself is already anticipated in Kant's critique of the argument.

Rowe's second objection, however, that the ontological argument begs the question, adds little if anything to Kant's prior objection in the First Critique. Although Kant does not specifically state that proponents of the argument are guilty of committing this informal fallacy, it is nevertheless clearly implied by his remarks. In response to the would-be proponent, he writes: 'You have already committed a contradiction when you have brought the concept of existence, under whatever disguised name, into the concept of a thing which you would think merely in terms of its possibility.' (A598/B626) ${ }^{12}$ What is highly interesting (and in some ways perplexing) about Kant's analysis of this defect in the argument, though, is that having identified this fallacious piece of reasoning he immediately proceeds to discuss how the proponent of the argument has committed a tautology, presumably on the assumption that that is the more serious problem facing the argument. The passage continues as follows:

\footnotetext{
${ }^{9}$ William Rowe, 'The Ontological Argument', p. 108.

${ }^{10}$ Kant, Critique of Pure Reason, p. 566.

${ }^{11}$ Ibid., p. 568.

12 Ibid., p. 566.
} 
If one allows you to do that, then you have won the illusion of a victory, but in fact you have said nothing; for you have committed a mere tautology. I ask you: is the proposition, This or that thing (which I have conceded to you as possible, whatever it may be) exists - is this proposition, I say, an analytic or a synthetic proposition? If it is the former, then with existence you add nothing to your thought of the thing; but then either the thought that is in you must be the thing itself, or else you have presupposed an existence as belonging to possibility, and then inferred that existence on this pretext from its inner possibility, which is nothing but a miserable tautology. The word 'reality', which sounds different from 'existence' in the concept of the predicate, does not settle it. For if you call all positing (leaving indeterminate what you posit) 'reality', then you have already posited the thing with all its predicates in the concept of the subject and assumed it to be actual, and you only repeat that in the predicate. If you concede, on the contrary, as in all fairness you must, that every existential proposition is synthetic, then how would you assert that the predicate of existence may not be cancelled without contradiction? since this privilege pertains only in the analytic propositions, as resting on its very character (A598/B626). ${ }^{13}$

Why does Kant construct his objection in this way? One possibility is that he assumes that forcing the proponent of the ontological argument into a dilemma - namely, either concede that the proposition 'God (defined as existing) exists' is an analytic proposition, in which case it commits a tautology, or concede that it is a synthetic proposition, in which case the predicate of existence can be denied without contradiction - is a better argumentative strategy (because a more effective criticism) than simply pointing out that she has begged the very question at issue. It is not entirely clear, however, that Kant fully appreciates the force of the objection he has just made, perhaps because he is so focused on laying out the dilemma mentioned above. Another possibility, then, is that Kant constructs his objection in the way he does because he conceives the smuggled assumption of God's actual existence in the premises of the ontological argument in terms of a logical self-contradiction, rather than what it straightforwardly is: an illicit assumption that commits an informal as opposed to a formal fallacy. Kant apparently thinks it necessary at this point to force the proponent of the ontological argument into a dilemma, but it seems to me that he has just made a fatal objection

\footnotetext{
${ }^{13}$ Ibid., p. 566.
} 
to the argument, and that no further argument is needed - including not only the aforementioned dilemma, but also the famous objection that 'existence is not a real predicate' which he proceeds to develop at A599/B627. If this interpretation is right, then what I have termed Kant's 'neglected objection' turns out to be doubly neglected, not only by those with an interest in Kant's critique of the traditional arguments for God's existence, but also partly by Kant himself. 